\title{
ATRX Mutation Analysis
}

National Cancer Institute

\section{Source}

National Cancer Institute. ATRX Mutation Analysis. NCI Thesaurus. Code C158852.

A procedure used to detect and identify mutations in the ALK gene. 